\title{
Potential Impacts of Mercosur-Egypt Free Trade
}

\section{Agreement}

\author{
Azza Kamal (PhD) \\ October University for Modern Sciences and Arts (MSA) \\ 26 July Mehwar Road intersection with Wahat Road, 6th October City. Egypt \\ Tel: 2-02-3837-1516Ｅ-mail: amkamal@msa.eun.eg
}

Received: August 9, 2017 Accepted: September 8, 2017

doi:10.5296/ber.v7i2.11935 URL: https://doi.org/10.5296/ber.v7i2.11935

\begin{abstract}
Mercosur-Egypt Free Trade Agreement was ratified in May 2017. This article examines potential gains for the agreement parties, through analysis of preferential margins, trade complementarity, and revealed comparative advantage indexes. Trade complementarity indexes show potential for higher trade between Egypt and Mercosur countries. Small preferential margins are expected to be gained for currently traded products which are subject to immediate tariff liberalization. Revealed comparative advantage analysis highlights several sectors which have the potential to benefit from the agreement.
\end{abstract}

Keywords: Mercosur, Egypt, Free Trade Agreement, Revealed Comparative Advantage

\section{Introduction}

Egypt signed a free trade agreement with the world's fourth largest trade bloc, Mercosur, in July 2010 (ICTSD, 2010). The agreement entered into force in May 2017, following ratification by the legislative authorities of its signatories (Egypt, Argentina, Paraguay, Uruguay). Venezuela, the fifth Mercosur member, is not a party to the Free Trade Agreement with Egypt, since it joined Mercosur after the agreement was finalized (Carrieri, 2015).

Mercosur (the Common Market of the South) was created in 1991 with the membership of Argentina, Brazil, Paraguay, and Uruguay. Venezuela joined the bloc in 2012. Together, the five Mercosur countries have a population size of 282.4 million inhabitants and GDP of \$3.3 trillion (World Bank, 2015). In addition to its five full members, Mercosur has five other associate members which are Bolivia, Chile, Colombia, Ecuador, Peru, Guyana and Suriname. Bolivia is in the process of obtaining a full member status. Being a customs union, full members of Mercosur apply a Common External Tariff with the rest of the world. Yet, there are exceptions for some sensitive products. Associate member are not required to apply the 
Common External Tariff, and do not enjoy duty free access to the markets of other Mercosur members. They only receive tariff reductions (Menicucci \& Gonçalves dos Santos \&Paschoal ,2014).

The Free Trade Agreement between Egypt and Mercosur is the first trade agreement the bloc signs with an African country, and the second one signed with a Middle Eastern country (Menicucci et al., 2014). Egypt is Mercosur's first trade partner in Africa, and the third partner among Arab countries (International Trade Center, 2015a). Mercosur's trade with Egypt and Arab countries has rapidly grown in the last decade. The economic and political cooperation between Arab and Latin American countries has witnessed a boost since the First Arab Latin American Summit which was held in 2005. The Fourth Summit was held in Riyadh, Saudi Arabia, on November 10, 2015 (Alaraby, 2015). One of the issues emphasized in the declaration of the Fourth Arab Latin American Summit was enhancing economic cooperation, trade and investment between the two regions (EkhbaryaTV, 2015).

Egypt's exports to the four founding Mercosur members (Argentina, Brazil, Paraguay, and Uruguay) grew from \$26 million in 2005 to \$183 million in 2014 (United Nations, 2015). Egypt's imports from the four Mercosur countries grew from $\$ 1.1$ billion in 2005 to $\$ 3.6$ billion in 2014 (United Nations, 2015). Brazil is Egypt's main trading partner among the Mercosur, and it ranks $11^{\text {th }}$ among Egypt's import partners. In 2014, Egypt's imports from Brazil and Argentina represented $60 \%$ and $32 \%$ of Egypt's imports from the Mercosur respectively, and $3.1 \%$ and $1.7 \%$ of Egypt's imports form the world. Together, Mercosur countries comprised 20\% of Egypt's imports of Agricultural products from the World in the same year. On the other hand, Mercosur countries only received $0.7 \%$ of Egypt's exports to the world, and Brazil comprised 93\% of Egypt's exports to the Mercosur in 2014.

Mercosur- Egypt Free Trade Agreement aims at liberalization of tariff barriers between Egypt and the four Mercosur countries, enhancing and supporting investment promotion activities, gradual liberalization of trade in services, and cooperation in the areas of technical, sanitary, and phyto-sanitary (plant health) standards and regulations. In the area of investment, the agreement stipulates for discussing the possibility of negotiating bilateral investment promotion agreements with a view to furthering investment flows and technology transfer. In the area of trade in services, the agreement states that members "will consider, in the Joint Committee, the possible modalities for opening negotiations on market access on trade in services". For technical, sanitary and phyto-sanitary standards and regulations, the agreement only calls for cooperation with a view to facilitating trade. The only area where the agreement stipulates for a specific plan of action and includes a schedule of commitments is elimination/reduction of tariffs imposed on goods (MDIC 2015). Therefore, the focus of this article is on trade in goods (merchandise trade) between Egypt and Mercosur, and the anticipated tariff liberalization resulting from the agreement.

The objectives of the current article are to: (1) identify and compare the sectors in which Egypt and each of the Mercosur countries have comparative advantage with a view to highlighting the sectors of potential higher trade and vertical/horizontal integration, and (2) identify the currently traded products between Egypt and Mercosur that are expected to 
benefit from trade liberalization under the trade agreement. Mercosur countries are defined in this article as the four members who are signatories to the Mercosur-Egypt Free Trade Agreement; namely Argentina, Brazil, Uruguay and Paraguay.

\section{Data and Methodology}

\subsection{Data}

Secondary data sources are employed. International trade data of Egypt and Mercosur countries are obtained from Trade Map (International Trade Center, 2015a), and Comtrade (United Nations, 2015). Applied tariff data are obtained from Trade Map and Market Access Map (International Trade Center, 2015b). Trade data at the product level are classified according to the 2007 version of the Harmonized Nomenclature System, because this is the version adopted in the schedules of tariff concessions annexed to Egypt-Mercosur Free Trade Agreement. Since classification of trade and tariff data from Trade Map follows the Harmonized Nomenclature System of 2012, concordance between the Harmonized Nomenclature Systems of 2007 and 2012 was performed based on the correlation tables between the two versions of the Harmonized system available from World Customs Organization (2012).

\subsection{Methodology}

The study employs descriptive methods to analyze the current trade structure between Egypt and Mercosur countries, following the Sussex approach for assessing free trade agreements (Evans et. al., 2006 \& 2007).Trade complementarity index, and revealed comparative advantage of the different sectors are calculated. Then, an analysis of how the tariff reductions included in the agreement affect the currently top traded products between Egypt and Mercosur is provided.

\subsubsection{Revealed Comparative Advantage}

International trade theory states that gains from trade come from specialization in a country's area of comparative advantage (World Trade Organization, 2015). The revealed comparative advantage (RCA) index, introduced by Balassa (1965), is used to discover the products in which a country has a comparative advantage. It is defined as the ratio of a country's share of the commodity in the country's total exports to the share of world exports of the commodity in total world exports. A country is said to have a revealed comparative advantage if the value of the index exceeds 1 and a revealed comparative disadvantage if the index's value is below 1. The larger the difference between countries' RCA indices, the more suitable they are as FTA partners.

The formula for the Revealed Comparative advantage (RCA) index is:

$$
R C A_{k}^{i}=\frac{X_{k}^{i} / X^{i}}{X_{k}^{w} / X^{w}}
$$

where $X_{k}^{i} / X^{i}$ refers to the share of exports (X) of product $k$ in the total exports of country $i$, and $X_{k}^{w} / X^{w}$ refers to the share of exports of product $k$ in the total world exports. An RCA 
index of greater than 1 indicates that country $i$ has a comparative advantage in exports of product $k$, and RCA index of less than 1 indicates that country $i$ has a comparative disadvantage in exports of the product in question.

\subsubsection{Trade Complementarity Index}

The Trade Complementarity Index measures the extent to which a country's exports overlap with what the other country imports (World Trade Organization, 2012). It is calculated on both the import side and the export side. A trade complementarity index on the import side measures the degree to which country i's imports matches with country j's exports. A trade complementarity index on the export side measures the degree to which country i's exports matches with country j's imports. When the Trade Complementarity index is equal to 100 , there is a perfect match between the imports of country $i$ and the exports of country $j$ and the two countries are "ideal partners" at least potentially (WITS 2013). Meanwhile, when the index is equal to zero, there is no matching between the exports of country $i$ and imports of country $\mathrm{j}$, and the two countries are potentially "intense competitors". It is calculated as follows:

$$
c^{i j}=100\left[1-\sum_{k=1}^{n}\left|m_{k}^{i}-x_{k}^{j}\right|\right],
$$

where $c^{i j}$ is the Trade Complementarity Index between countries $\mathrm{i}$ and $\mathrm{j}, m_{k}^{i}$ is the share of product $\mathrm{k}$ in the total imports of country $\mathrm{i}$ from the world, and $x_{k}^{j}$ is the share of product $\mathrm{k}$ in total exports of country $\mathrm{k}$ to the world (World Trade Organization 2012). The index is calculated at a the six-digit level of the Harmonized Nomenclature System (highly disaggregated level) in order to provide a better reflection of potential trade between Egypt and each of the Mercosur members at the product rather than the sector level.

\section{Results and Discussion}

This section starts with an overview of Egypt's trade with Mercosur countries. Revealed Comparative Advantage and Trade Complementarity indexes for Egypt and Mercosur countries are then employed to identify the main sectors of potential higher trade, and increased vertical/horizontal integration between Egypt and Mercosur countries. This is followed by analysis of how the top products traded between Egypt and Mercosur countries are affected by the schedule of tariff liberalization.

\subsection{Egypt's Trade with Mercosur Members}

Egypt's imports from Mercosur countries averaged \$3.9 billion in 2012-2014, while exports averaged \$236 million. Brazil is Egypt's main trade partner among Mercosur countries, followed by Argentina, then Uruguay, and Paraguay. Mercosur countries supply $5.6 \%$ of Egypt's imports from the world, and receive $0.8 \%$ of Egypt's exports to the world (Table 1). 
Table 1. Trade between Egypt and Mercosur Countries- Average of 2012-2014 (\$ Million)

\begin{tabular}{|l|l|l|l|l|l|l|}
\hline & $\begin{array}{l}\text { Egypt's Imports } \\
\text { from the country } \\
\text { \$ Million) }\end{array}$ & $\begin{array}{l}\text { Egypt's Exports } \\
\text { to the Country } \\
\text { \$ Million) }\end{array}$ & $\begin{array}{l}\text { Share in Egypt's } \\
\text { Imports from } \\
\text { Mercosur Countries }\end{array}$ & $\begin{array}{l}\text { Share in Egypt's } \\
\text { Exports to Mercosur } \\
\text { Countries }\end{array}$ & $\begin{array}{l}\text { Share in Egypt's } \\
\text { Imports from the } \\
\text { World }\end{array}$ & $\begin{array}{l}\text { Share in Egypt's } \\
\text { Exports } \\
\text { world }\end{array}$ \\
\hline Argentina & 1,283 & 22 & $33 \%$ & $9 \%$ & $1.8 \%$ & $0.1 \%$ \\
\hline Brazil & 2,418 & 202 & $62 \%$ & $86 \%$ & $3.5 \%$ & $0.7 \%$ \\
\hline Paraguay & 47 & 1 & $1 \%$ & $1 \%$ & $0.1 \%$ & $0 \%$ \\
\hline Uruguay & 162 & 11 & $4 \%$ & $5 \%$ & $0.2 \%$ & $0.04 \%$ \\
\hline Total Trade & 3,909 & 236 & $100 \%$ & $100 \%$ & $5.6 \%$ & $0.8 \%$ \\
\hline
\end{tabular}

Source: International Trade Center, 2015a

\subsection{Trade Complementarity Index}

The Trade Complementarity Indexes are calculated using a disaggregated product definition (six-digit level of the Harmonized Nomenclature System) for Egypt's exports to and imports from each of the Mercosur countries. A trade complementarity index which is equal to 100 (zero) indicates full (no) overlap between the imports and exports of the two countries in question. Table 2 shows moderate complementarity in trade between Egypt and each of the Mercosur countries, as the trade complementarity index ranges between 38.1 and 61.5. Although Egypt's current exports to Uruguay are low, the trade complementarity index of Egypt's exports to that country is 61.5 , which is close to the trade complementarity index for Egypt's exports to its major export partner, Italy (calculated from Trade Map 2015). The same applies to Paraguay. Egypt's export complementarity indexes with Brazil and Argentina are 53.4 and 45.6 which imply potential for increased exports from Egypt to Mercosur countries.

Table 2. Trade Complementarity Indexes (Average 2012-2014)

\begin{tabular}{|l|l|l|l|l|}
\hline & Argentina & Brazil & Paraguay & Uruguay \\
\hline Egypt's Exports & 45.6 & 53.3 & 52.5 & 61.5 \\
\hline Egypt's Imports & 49.5 & 54.6 & 39.9 & 38.1 \\
\hline
\end{tabular}

Source: Calculated from International Trade Center (2015a)

\subsection{Revealed Comparative Advantage}

Agricultural products constitute a large share of Mercosur's world exports. Agricultural products represent 53\%,39\%, 75\%, and 67\% of the total world exports of Argentina, Brazil, Paraguay, and Uruguay respectively. Meanwhile, agricultural products only represent $19 \%$ of Egypt's agricultural exports to the world (World Trade Organization, 2015).

The revealed comparative advantage indexes of the world exports of Egypt and each of the Mercosur countries are calculated for each of the 99 sectors (chapters) of the Harmonized Nomenclature (HS 2012). It is found that Brazil, Argentina, and Uruguay have comparative advantage in 33, 27, and 25 sectors respectively. Meanwhile, Egypt has a comparative advantage in 47 sectors. Out of the 24 chapters of agricultural products included in the Harmonized Nomenclature, Mercosur countries have a comparative advantage in 18 chapters, and Egypt has a comparative advantage in 14 chapters. 
The revealed comparative advantage index identifies the products which represent a high share of the country's exports in comparison to the share of such products in world exports. In other words, revealed comparative advantage index reflects the relative importance of the product in the country's exports. However, it is not a reflection of the share of the country's products in world exports. Brazil's share in world exports exceeds 10\% for ten sectors. Argentina's share in world exports of 8 sectors exceeds 10\%. Meanwhile, Egypt's share in world exports of any sector does not exceed $1 \%$ except for five sectors where the maximum share is $2.4 \%$ (International Trade Center, 2015).

Table 3 shows the sectors for which Mercosur countries have revealed comparative advantage in exports to the world and for which Egypt does not have a revealed comparative advantage in exports. Those sectors are the ones with the highest potential of trade between Egypt and Mercosur countries. Among such sectors, there are nine sectors in which Egypt has a comparative disadvantage in imports. The comparative disadvantage in imports means that the sector's share in Egypt's imports is high compared to the share of that sector in world imports. Those sectors are live animals, meat, cereals, and animal fodder. Trade in the sectors in which the exporting countries have comparative advantage prior to the free trade agreement implies that trade liberalization under the agreement will not result in negative trade diversion impacts for those sectors (Evans et al., 2007).

Table 3. The sectors in which Mercosur countries have Revealed Comparative Advantage (RCA) and Egypt has Comparative Disadvantage (Average of 2012-2014)

\begin{tabular}{|c|c|c|c|c|c|c|c|c|c|}
\hline $\begin{array}{l}\text { HS Chapter } \\
\text { Code }\end{array}$ & Description & $\begin{array}{l}\text { Brazil } \\
\text { RCA }\end{array}$ & $\begin{array}{l}\text { Argentina } \\
\text { RCA }\end{array}$ & $\begin{array}{l}\text { Uruguay } \\
\text { RCA }\end{array}$ & $\begin{array}{l}\text { Paraguay } \\
\text { RCA }\end{array}$ & \begin{tabular}{|l} 
Egypt \\
Comparative \\
Disadvantage \\
in Imports \\
\end{tabular} & $\begin{array}{l}\text { Egypt imports } \\
\text { from Mercosur } \\
\text { \$ Million }\end{array}$ & $\begin{array}{l}\text { Egypt imports } \\
\text { from world } \\
\text { \$Million }\end{array}$ & $\begin{array}{l}\text { Mercosur } \\
\text { Exports to world } \\
\text { \$ Million }\end{array}$ \\
\hline 1 & $\begin{array}{l}\text { Live animals; } \\
\text { animal products }\end{array}$ & 2.6 & & 12.4 & 1.5 & & 34 & 135 & 911 \\
\hline 2 & $\begin{array}{l}\text { Meat and edible meat } \\
\text { offal }\end{array}$ & 9.3 & 3.6 & 24.7 & 3.4 & 19.3 & 750 & 1623 & 20299 \\
\hline 3 & Fish, and other aquatics & & 4.0 & 2.8 & 2.3 & & 13 & 562 & 1986 \\
\hline 9 & $\begin{array}{l}\text { Coffee, tea, matte } \\
\text { and spices }\end{array}$ & 12.2 & 1.4 & & 1.2 & & 7 & 522 & 6761 \\
\hline 10 & Cereals & 3.0 & 11.7 & 14.4 & 10.4 & 9.8 & 672 & 5052 & 11158 \\
\hline 16 & Meat or fish Preparations & 2.6 & & 1.8 & & & 10 & 193 & 1705 \\
\hline 22 & Beverages, and spirits & & 2.0 & & & & 0 & 60 & 2079 \\
\hline 23 & Animal Fodder & 7.0 & 40.0 & & 2.9 & 25.9 & 536 & 1032 & 21392 \\
\hline 24 & Tobacco and substitutes & 4.8 & 1.9 & 2.7 & 1.7 & & 33 & 289 & 2896 \\
\hline 26 & Ores, slag and ash & 10.8 & 1.6 & & & & 293 & 561 & 30089 \\
\hline 36 & $\begin{array}{l}\text { Explosives; pyrotechnic } \\
\text { products; matches }\end{array}$ & 1.4 & & & 3.4 & & 7 & 139 & 796 \\
\hline 40 & $\begin{array}{l}\text { Rubber and articles } \\
\text { thereof }\end{array}$ & & & 1.4 & 1.3 & & 3 & 975 & 2405 \\
\hline 44 & Wood and articles thereof & 1.4 & 10.0 & & & 1.1 & 4 & 1870 & 3239 \\
\hline 47 & Pulp of wood & 9.2 & & & 1.1 & & 35 & 198 & 5441 \\
\hline 78 & Lead and articles thereof & & 1.7 & & & & 0 & 26 & 60 \\
\hline 83 & $\begin{array}{l}\text { Miscellaneous articles } \\
\text { of base metal }\end{array}$ & 1.3 & & & & & 0 & 171 & 1124 \\
\hline 87 & $\begin{array}{l}\text { Vehicles other than } \\
\text { railway tramway }\end{array}$ & & 1.6 & & & & 65 & 5243 & 18419 \\
\hline 88 & Aircraft, and parts thereof & 1.5 & & & & & 0 & 66 & 4272 \\
\hline 89 & $\begin{array}{l}\text { Ships, boats and } \\
\text { floating structures }\end{array}$ & 1.3 & & & & & 0 & 52 & 2353 \\
\hline
\end{tabular}

Source: Calculated Using data from International Trade Center(2015a) 


\section{Macrothink $\Delta$ Institute ${ }^{\text {th }}$}

Concerning possible candidates for increased exports from Egypt to Mercosur, table 4 shows the sectors in which Egypt has a comparative advantage in exports and Mercosur countries do not. Such sectors include fertilizers, plastic products, carpets, man-made fibers, glass and glass ware, and copper products. Fertilizers already constitute more than $40 \%$ of Egypt's exports to Mercosur. Plastics, glass and glassware, carpets, and man-made fibers represent $10 \%, 4 \%, 1 \%$, and $1 \%$ respectively of Egypt exports to Mercosur.

Table 4. The Sectors in which Egypt has Revealed Comparative Advantage(RCA) and Mercosur Countries Do Not Have Comparative Advantage (Average of 2012 to 2014)

\begin{tabular}{|c|c|c|c|c|c|}
\hline $\begin{array}{l}\text { Chapter } \\
\text { Code }\end{array}$ & Description & Egypt's RCA & $\begin{array}{l}\text { Egypt Exports } \\
\text { to Mercosur } \\
\text { \$ Million }\end{array}$ & $\begin{array}{l}\text { Average Merc } \\
\text { imports from world } \\
\text { \$Million }\end{array}$ & $\begin{array}{l}\text { Average Egypt } \\
\text { exports to world } \\
\text { \$ Million }\end{array}$ \\
\hline 6 & $\begin{array}{l}\text { Live trees and other plants; } \\
\text { bulbs, roots and the }\end{array}$ & 2.4 & 0 & 54 & 68 \\
\hline 18 & Cocoa and cocoa preparations & 2.2 & 0 & 657 & 104 \\
\hline 27 & $\begin{array}{l}\text { Mineral fuels, mineral oils } \\
\text { and products }\end{array}$ & 1.8 & 31 & 59579 & 7567 \\
\hline 31 & Fertilizers & 9.9 & 102 & 10703 & 1071 \\
\hline 39 & Plastics and articles thereof & 1.9 & 24 & 13558 & 1476 \\
\hline 48 & $\begin{array}{l}\text { Paper and paperboard; articles } \\
\text { of paper pulp }\end{array}$ & 1.5 & 0 & 3569 & 379 \\
\hline 54 & $\begin{array}{l}\text { Man-made filaments; strip } \\
\text { and the like products }\end{array}$ & 1.2 & 0 & 1904 & 92 \\
\hline 55 & Man-made staple fibres & 1.7 & 2 & 1384 & 114 \\
\hline 56 & $\begin{array}{l}\text { Wadding, felt and nonwovens; } \\
\text { special yarns; twine, }\end{array}$ & 1.1 & 0 & 480 & 17 \\
\hline 57 & $\begin{array}{l}\text { Carpets and other textile } \\
\text { floor coverings }\end{array}$ & 16.6 & 2 & 151 & 399 \\
\hline 58 & $\begin{array}{l}\text { Special woven fabrics; } \\
\text { tufted textile fabrics }\end{array}$ & 8.9 & 2 & 151 & 399 \\
\hline 61 & $\begin{array}{l}\text { Articles of apparel and } \\
\text { clothing accessories, knit }\end{array}$ & 1.7 & 1 & 1751 & 499 \\
\hline 62 & $\begin{array}{l}\text { Articles of apparel and } \\
\text { clothing accessories, not knit }\end{array}$ & 2.6 & 1 & 2014 & 806 \\
\hline 63 & Other made up textile articles & 3.5 & 0 & 515 & 311 \\
\hline 69 & Ceramic products & 5.3 & 0 & 1041 & 464 \\
\hline 70 & Glass and glassware & 3.1 & 9 & 1290 & 340 \\
\hline 74 & Copper and articles thereof & 1.2 & 0 & 3017 & 348 \\
\hline 94 & $\begin{array}{l}\text { Furniture; bedding, mattresses, } \\
\text { mattress supports }\end{array}$ & 1.03 & 1 & 2677 & 358 \\
\hline
\end{tabular}

Source: Calculated Using data from International Trade CenterTrade Map(2015)

Table 5 shows the sectors in which both Egypt and Mercosur countries have comparative 
advantage in exports. Those sectors can either be candidates for intense competition between the countries, or candidates for intra-industry trade. Such sectors include vegetable and animal fats \& oils, sugar and confectionary, vegetables, fruits, cotton, iron and steel products, and aluminum products.

In the vegetable and animal fats sector, a large share of Mercosur's exports are in the form of crude vegetable oil, while a large share of Egypt's exports is in the form of refined vegetable oil. On average, Egypt imported crude vegetable oil from Mercosur countries valued at $\$ 188$ million between 2012 and 2014, which represented 13\% of Egypt imports of vegetable oil from the world. Meanwhile, Egypt exported vegetable oils (mainly refined) valued at \$234 million in the same period (International Trade Center, 2015). Egypt's main market for refined vegetable oil is neighboring Arab countries. Thus, vegetable oil is a candidate for vertical integration between Egypt and Mercosur. Egypt can import raw vegetable oil from Mercosur, refine it, and export refined vegetable oil to neighboring markets (It is important to note that such analysis is merely based on analysis of trade flows rather than full market research. Also, the rules of origin were not considered. Egypt exports refined vegetable oils to members of the Great Arab Free Trade Agreement, and Agadir Agreement. To enjoy preferential tariffs under such agreements, a certain level of value added from the agreement members is required for each product).

In the sugar and confectionary sector, Brazil's comparative advantage is mainly in raw sugar and sucrose. Meanwhile, Egypt's comparative advantage is in molasses. Egypt imports raw sugar cane from Brazil, and exports molasses to Mercosur and other countries. There are several ways in which molasses can be produced. It can be a by-product of sugar refining from raw sugar cane or a by-product of the initial process of extraction of raw sugar from sugar cane (Pérez, 1995). No information is available for the author about the process of production of molasses in Egypt. Thus, it is difficult to determine whether sugar is a candidate for vertical integration between Egypt and Mercosur.

As for cotton, Egypt is specialized in production of long staple cotton, while Brazil is specialized in production of short staple cotton. The two types of cotton have different uses. Egypt exports long staple cotton to Brazil, and imports short-staple cotton from Brazil. Thus, cotton trade between Egypt and Mercosur is an example of horizontal integration.

The above provided examples of possible vertical and horizontal integration between Egypt and Mercosur through intra-industry trade. However, it is worthy to note that trade in the same sector does not necessarily involve intra-industry trade. Another possibility is that the sector definition is too aggregated such that the products included in the sector are not similar. For example, both Egypt and Mercosur have comparative advantage in exports of chapter 12 which includes oilseeds and pharmaceutical plants. Mercosur's exports are concentrated in oilseeds (soybeans) while Egypt's exports are concentrated in pharmaceutical plants. 


\section{$\triangle 1$ Macrothink}

Business and Economic Research

ISSN 2162-4860

2017, Vol. 7, No. 2

Table 5. The Sectors in which Both Egypt and Mercosur Have Comparative Advantage

(Average 2012-2014)

\begin{tabular}{|l|l|l|l|l|l|l|l|l|l|l|}
\hline \multirow{2}{*}{$\begin{array}{l}\text { Chapter } \\
\text { Code }\end{array}$} & Description & \multicolumn{3}{|l|}{ Revealed Comparative Advantage } & \multicolumn{3}{l|}{ Trade Balance (\$ Million) } \\
\hline & & Brazil & Argentina & Urugua & Paraguay & Egypt & Egypt- Mercosur & Egypt-World & Mercosur -World \\
\hline 12 & Oil seeds and oleaginous fruits & 18.7 & 11.0 & 31.7 & 45 & 1.9 & -428 & -1047 & 28768 \\
\hline 17 & Sugars and sugar confectionery & 17.2 & & & 3.1 & 4.1 & -425 & -351 & 11021 \\
\hline 15 & Animal or vegetable fats and oils & 1.3 & 12.0 & & 10.2 & 1.3 & -188 & -1216 & 5722 \\
\hline 72 & Iron and steel & 1.9 & & & & 1 & -21 & -3405 & 4570 \\
\hline 7 & Edible vegetables and certain root & & 2.1 & & & 10.6 & -12 & 465 & -268 \\
\hline 21 & Miscellaneous edible preparations & 1.4 & & & & 2.1 & -8 & -12 & 267 \\
\hline 35 & $\begin{array}{l}\text { Albuminoidal substances; } \\
\text { modified starches }\end{array}$ & 1.2 & 2.8 & & & 1.5 & -7 & -79 & -103 \\
\hline 38 & Miscellaneous chemical products & & 3.0 & & & 1.5 & -3 & -454 & -4272 \\
\hline 33 & Essential oils; perfumery, cosmetic & & 1.7 & & & 2.7 & -2 & 52 & -953 \\
\hline 68 & Articles of stone, & 2.1 & & & & 4 & 0 & 168 & 342 \\
\hline 8 & plaster, cement, asbestos & & & & & & & & \\
\hline 25 & Salt; Sulphur; earths and stone & 1.5 & & & & 6 & 6 & 570 & \\
\hline 41 & Raw hides and skins, leather & 6.8 & 7.6 & 18.0 & 10.4 & 3.8 & 0 & 224 & -482 \\
\hline 20 & Preparations of vegetables, fruit nuts & 3.0 & 4.5 & & & 4.5 & 1 & 155 & 3718 \\
\hline 52 & Cotton & 2.0 & & & & 5.2 & 11 & 232 & 2683 \\
\hline 11 & Products of the milling industry malt. & & 7.5 & 21.6 & 2.5 & 2.7 & 0 & -154 & 1124 \\
\hline 19 & Preparations of cereals, flour, starch & & 1.9 & & & 1.2 & 0 & 25 & -107 \\
\hline
\end{tabular}

Source: Calculated Using data from Trade Map(2015)

\subsection{Tariff Liberalization under the Mercosur- Egypt Free Trade Agreement}

Customs duties and charges having equivalent effect imposed by each Party on imports of originating goods in the other Party are gradually eliminated according to five categories: Category A - upon entry into force of this Agreement; Category B - 25\% reduction every year, starting the first day of the entry into force of the agreement; Category $\mathrm{C}-12.5 \%$ every year until full elimination in eight years; Category D - 10\% every year; and Category E sensitive products, where full elimination of tariffs is determined by further negotiations (MDIC, 2015).

The base for reduction of customs duties and charges is the most-favored-nation tariff applied in 2010. After entry into force of the agreement, any tariff reductions on an MFN basis will serve as the new base for tariff reduction. This means that the base for tariff reduction between the signatory parties to the agreement is the applied tariff prevailing in any time period. However, if the applied tariff is greater than the tariff applied in 2010, the tariff prevailing in 2010 serves as the ceiling for tariffs applied between the signatories to the agreement (MDIC, 2015).

\subsubsection{Egypt's Imports from Mercosur}

Mercosur countries are main exporters of agricultural commodities to Egypt, and to the world. Agricultural and processed agricultural products represented $80 \%$ of Egypt's imports from Mercosur countries in 2014 (calculated from Table 6). Mercosur countries supplied 20\% of Egypt's imports of agricultural products from the world in the same year (International Trade 
Center, 2015a). Brazil and Argentina are the main import partners of Egypt among Mercosur countries. Six agricultural products represent $72 \%$ of Egypt's imports from Mercosur: maize, bovine meat, soya bean, soya bean oil cake (animal fodder), raw sugar cane, and whole chicken.

Table 7 shows Egypt's top imports from Mercosur countries defined at the 6-digit level of product classification. The 22 products included in the table represent $94 \%$ of the value of Egypt's imports from Mercosur countries. The table also shows the tariffs that Egypt applies on those products, and the expected tariff reductions that those products will benefit from under Egypt-Mercosur Free Trade Agreement. It is clear from the table that the top imported agricultural products which lie under category A (immediate elimination of tariffs) are already subject to zero tariffs. Those products are maize, soya beans, bovine live animals, crude soya bean oil, and frozen bovine cuts. Therefore, they are not affected by the agreement. Soya bean oil cake, flavored refined sugar, and unmanufactured tobacco are subject to ad valorem equivalent tariffs of 5\%, 18\%, and $18.1 \%$ respectively. However, they are classified under category $\mathrm{E}$ where trade liberalization is postponed. Bovine edible offal and raw sugar cane are subject to tariffs of $10 \%$ and $2 \%$, but they will benefit from prolonged tariff elimination over a period of eight years.

Frozen fowls of gallous domesticus (frozen whole chicken) have long been protected by the Egyptian authorities through sanitary and technical regulations. Following the avian flu epidemic in Egypt, the Egyptian authorities allowed importation of frozen whole chicken under strict regulations. Currently, 94\% of Egypt's imports of frozen whole chicken come from Brazil. Small quantities are imported from Argentina and Uruguay. The current tariff applied on Egypt's imports of frozen whole chicken is 30\% (International Trade Center, 2015a). The FTA agreement stipulates for limited trade liberalization under tariff rate quotas. The applied tariff on whole chicken will be reduced by 30\% for 1000 tons of Egypt's imports from Brazil, 400 tons of Egypt's imports from Argentina, and 500 tons for Egypt's imports from each of Uruguay and Paraguay (MDIC, 2015). According to Brazil's trade data, the quantity of frozen whole chicken Egypt imported from Brazil ranged between 76.1 thousand and 114 thousand tons during the period 2010-2014 (International Trade Center, 2015a). Meanwhile, imported quantities from Argentina and Uruguay during the same period were smaller than the quotas that will be allotted to them under the FTA.

Non-agricultural products represent 20\% of Egypt's imports from Mercosur. Although Mercosur countries have a small share in Egypt's imports of non-agricultural products in general, they have a high share in the Egyptian market of the few non-agricultural products they export to Egypt. The top Egyptian imports from Mercosur are iron ores, household refrigerators, line pipes, motor vehicle parts, pig iron, and chassis of certain types of cars. Iron ores and pig iron are subject to immediate elimination of tariffs, but the applied tariffs imposed on them are zero and $2 \%$ respectively. Chassis, motor vehicle parts, and loaders will receive prolonged tariff liberalization over seven years, and are subject to tariffs ranging from $2 \%$ to $8.6 \%$. Household refrigerators and line pipes are subject to tariffs of $30 \%$ and $10 \%$ respectively. They will benefit from prolonged trade liberalization over 10 years (category D). 


\subsubsection{Egypt's Exports to Mercosur}

Egypt's exports to Mercosur are represented by mirror data of Mercosur imports from Egypt in Table 9. Mercosur's import data are used instead of Egypt's export data because the purpose of this section is to examine the preferential margins which Egypt's exports will obtain under the FTA. Mercosur's applied tariffs and schedule of tariff liberalization under the FTA are represented at the 8-digit level of the international Harmonized System of Product codes. Until the 6-digit level of product disaggregation, countries use the same product classification. At more disaggregated levels like the 8-digit level, countries have their own classification. Therefore, identifying the tariffs imposed on Mercosur's imports from Egypt required using Mercosur's product classification.

Brazil is the main export partner of Egypt among Mercosur countries. Non-agricultural products constitute most of Egypt's exports to Mercosur countries. Superphosphate fertilizers represent about $45 \%$ of Egypt's exports to Mercosur countries. This is followed by non-cellular polyethylene terephthalate sheets and films, non-pneumatic tires, cotton and acrylic yarns, parts of water boilers, and float glass. Mercosur receives $11 \%, 10 \%$ and $12 \%$ of Egypt's total exports of fertilizers, rubber products, and razors respectively. The main agricultural products exported by Egypt to Mercosur are cotton, dried onions, prepared olives, and parts of perfumery plants. Mercosur receives 5.5\% and 5.1\% of Egypt's total exports of dried onions and cotton respectively.

Under Egypt-Mercosur Free Trade Agreement, there are products for which Mercosur countries provide the same concessions to Egypt, while there are other products for which Mercosur countries offer different concessions. Therefore, the following analysis presents the expected trade liberalization under Egypt-Mercosur FTA for each of the Mercosur countries separately. Brazil is the main export partner of Egypt among the Mercosur countries. Brazil received $89 \%$ of Egypt's exports to Mercosur in 2014, followed by Argentina (6\%), Uruguay (4\%), and Paraguay (1\%). In 2013, Brazil received 67\% of Egypt's exports to Mercosur, while Argentina's share in Egypt's exports to Mercosur was 29\%, followed by Uruguay (3.7\%), and Paraguay (0.2\%). Egypt's exports of liquefied natural gas to Argentina made the difference in trade patterns between 2013 and 2014 (International Trade Center, 2015a). 


\section{$\triangle 1$ Macrothink}

Business and Economic Research

ISSN 2162-4860

2017, Vol. 7, No. 2

Table 6. Value of Egypt's imports from Mercosur countries by product, current applied tariff on each product, and expected trade liberalization for each product under Mercosur- Egypt Free Trade Agreement

\begin{tabular}{|c|c|c|c|c|c|c|c|c|c|c|}
\hline \multirow{2}{*}{$\begin{array}{l}\text { Product } \\
\text { code }\end{array}$} & \multirow[t]{2}{*}{ Product label } & \multirow{2}{*}{\begin{tabular}{|l|} 
Total \\
Imports of \\
Egypt \\
from \\
Mercosur \\
in 2014 \\
(\$ Million) \\
\end{tabular}} & \multicolumn{4}{|c|}{\begin{tabular}{|l|l|l|} 
Value of Egypt's Imports from Each \\
Mercosur Country in 2014 (\$ Million)
\end{tabular}} & \multirow{2}{*}{\begin{tabular}{|l} 
Product \\
Share in \\
Egypt's \\
total \\
imports \\
from \\
Mercosur
\end{tabular}} & \multirow{2}{*}{\begin{tabular}{|l} 
Share of \\
Mercosur \\
in \\
Egypt's \\
Imports \\
from the \\
World
\end{tabular}} & \multirow{2}{*}{$\begin{array}{l}\text { Equivalent } \\
\text { ad } \\
\text { valorem } \\
\text { tariff } \\
\text { applied by } \\
\text { Egypt in } \\
2014(\%)\end{array}$} & \multirow{2}{*}{ 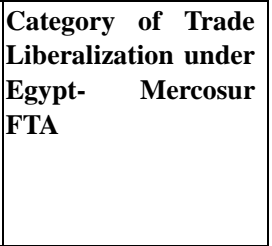 } \\
\hline & & & Argentina & Brazil & Uruguay & Paraguay & & & & \\
\hline TOTAL & All products & 3,632 & 1175 & 2192 & 188 & 76 & $100 \%$ & $5.1 \%$ & - & - \\
\hline \multicolumn{11}{|c|}{ Agricultural and Processed Agricultural Products } \\
\hline 100590 & Maize (corn) & 672 & 378 & 293 & & & $18 \%$ & $35 \%$ & 0 & A \\
\hline 020230 & \begin{tabular}{|l|l|}
$\begin{array}{l}\text { Frozen } \\
\text { cuts }\end{array}$ & Bovine \\
\end{tabular} & 593 & - & 592 & 0.10 & 0.20 & $16 \%$ & $50 \%$ & 0 & A \\
\hline 120190 & Soya beans & 542 & 158 & 154 & 161 & 69 & $15 \%$ & $51 \%$ & 0 & A \\
\hline 230400 & $\begin{array}{l}\text { Soya-bean } \\
\text { oil-cake }\end{array}$ & 533 & 527 & - & - & 5 & $15 \%$ & $83 \%$ & 5 & E \\
\hline 170113 & Raw cane sugar & 149 & - & 149 & - & - & $4 \%$ & $62 \%$ & 2 & C \\
\hline 20712 & \begin{tabular}{|l|} 
Whole Frozen \\
Chicken
\end{tabular} & 137 & 0.36 & 136 & 1.2 & 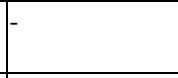 & $4 \%$ & $94 \%$ & 30 & $\begin{array}{l}\text { Tariff Reduction } \\
\text { within quota }\end{array}$ \\
\hline 150710 & $\begin{array}{l}\text { Crude } \\
\text { Soya-bean oil }\end{array}$ & 56 & 55.9 & & & & $2 \%$ & $52 \%$ & 0 & A \\
\hline 10290 & \begin{tabular}{|l|l|} 
Live Bovine \\
Animals
\end{tabular} & 34 & - & 16.8 & 17.5 & & $1 \%$ & $41 \%$ & 0 & A \\
\hline 240110 & \begin{tabular}{|l|}
$\begin{array}{l}\text { Unmanufactured } \\
\text { Tobacco }\end{array}$ \\
\end{tabular} & 33 & 0.1 & 32.7 & - & 0.04 & $1 \%$ & $37 \%$ & 18.1 & $\mathrm{E}$ \\
\hline 170191 & $\begin{array}{|lr|}\text { Refined } & \text { sugar } \\
\text { with } & \text { added } \\
\text { flavor } & \text { color } \\
\end{array}$ & 19 & - & 18.9 & - & - & $1 \%$ & $99 \%$ & 10 & $\mathrm{E}$ \\
\hline 20629 & \begin{tabular}{|l|}
$\begin{array}{l}\text { Bovine edible } \\
\text { offal, frozen }\end{array}$ \\
\end{tabular} & 17 & - & 16.5 & - & - & $0.5 \%$ & $18 \%$ & 5 & C \\
\hline \multicolumn{11}{|c|}{ Non- Agricultural Products } \\
\hline $\begin{array}{ll}260112 \\
260111\end{array}$ & \begin{tabular}{|l|l|} 
Iron ores \& \& \\
concentrates
\end{tabular} & 292 & - & 292 & - & - & $8.3 \%$ & $53 \%$ & 0 & A \\
\hline 999999 & $\begin{array}{l}\text { Commodities not } \\
\text { elsewhere } \\
\text { specified }\end{array}$ & 187 & - & 187 & - & - & $5 \%$ & $72 \%$ & & \\
\hline 870600 & $\begin{array}{lr}\text { Chassis } & \text { for } \\
\text { certain types } & \text { of } \\
\text { vehicles } & \end{array}$ & & - & 40.2 & - & - & $1 \%$ & $47 \%$ & 5 & C \\
\hline 841821 & $\begin{array}{l}\text { Refrigerators, } \\
\text { household type, } \\
\text { compression-type }\end{array}$ & 25 & - & 25.4 & - & - & $1 \%$ & $24 \%$ & 30 & D \\
\hline 470500 & $\begin{array}{l}\text { Semi-chemical } \\
\text { wood pulp }\end{array}$ & 24 & - & 23.7 & - & - & $1 \%$ & $20 \%$ & 2 & A \\
\hline 870899 & \begin{tabular}{|lr} 
Motor & vehicle \\
parts & nes \\
$(8708999090)$
\end{tabular} & 23 & - & 22.5 & - & - & $1 \%$ & $6 \%$ & 8.6 & $\begin{array}{l}\text { A, C }(95 \% \text { of the } \\
\text { imports are under C) }\end{array}$ \\
\hline 730619 & $\begin{array}{l}\text { Line pipe used } \\
\text { for oil or gas } \\
\text { pipelines }\end{array}$ & 22 & 16.5 & 5.6 & 0.1 & - & $1 \%$ & $8 \%$ & $10 \%$ & $\mathrm{D}$ \\
\hline 720150 & Alloy pig iron, & 18 & & 17.7 & - & - & $0.5 \%$ & $35 \%$ & 2 & A \\
\hline 842951 & $\begin{array}{l}\text { Front end shovel } \\
\text { loaders }\end{array}$ & 12 & & 11.7 & - & - & $0.3 \%$ & $9 \%$ & 5 & C \\
\hline & Other Products & 205 & 39 & 156 & 9 & 2 & $6 \%$ & & & \\
\hline
\end{tabular}

Category A: Immediate tariff elimination on the date of the agreement's into force; Category B: tariff elimination in four years starting the date of the agreement's entry into force; Category C: Tariff elimination in eight years starting the date of the agreement's entry into force; Category D: Tariff elimination in ten years starting the date of the agreement's entry into force; Category E: Tariff liberalization is to be negotiated.

Source: Trade data are from International Trade Center (2015a); Tariff data are International Trade Center (2015b); Trade Liberalization categories are from Free Trade Agreement between Mercosur and Egypt-Annex II. 
Half of all the tariff lines that Egypt exports to Brazil are eligible to immediate tariff elimination. However, superphosphate fertilizers which are already subject to zero tariffs constitute most of those exports (47\% of Egypt's exports to Brazil). Medical tools, anise seeds, and wood furniture, which are currently subject to $16 \%, 10 \%$ and $18 \%$ tariffs respectively, follow superphosphate fertilizers in the list of top Egyptian exports which will benefit from immediate tariff elimination. Yet, Egypt's exports to Brazil of each of those products did not exceed $\$ 1.5$ million in 2014 .

Category B products, which are subject to tariff liberalization over 4 years, represent $10.5 \%$ of Egypt's current exports to Brazil. Those products include cotton, prepared olives, razors, polyethylene products, and plant parts which are subject to tariffs of $6 \%, 14 \%, 18 \%, 14 \%$, and $8 \%$ respectively. With the exception of cotton and razors, Egypt has a comparative advantage in the exports of those products, and Brazil has a comparative disadvantage. This implies that there is a high potential of the increase in Egypt's exports of those products to Brazil when the tariffs are removed. This even applies to cotton, because Egypt and Brazil produce cotton of different staple lengths.

Category $\mathrm{C}$ products, which are subject to tariff liberalization over 8 years, constitute $15.5 \%$ of Egypt's exports to Brazil in 2014. Non-pneumatic tires represent the highest share of products subject to category C (7.3\% of Egypt's total exports to Brazil), and are subject to a tariff of $16 \%$. Mineral and chemical fertilizers containing three elements are already subject to zero tariffs. Other products benefiting from trade liberalization under category $\mathrm{C}$ include aluminum alloys currently subject to a $16 \%$ tariff, medical dressing adhesives, and tire cord fabrics. Egypt's exports of each of those products to Brazil did not exceed \$1 million in 2014.

Category D products, which are subject to tariff liberalization in 10 years constitute $23.7 \%$ of Egypt's exports to Brazil. Dried onions, Non-cellular polyethylene terephthalate sheets, cotton yarns (several tariff lines), float glass, parts of water boilers, and cotton T-shirts constitute most of those products. They are subject to tariffs ranging between $10 \%$ and $35 \%$ as shown in table 9. Egypt has a high comparative advantage in exports of dried onion and T-shirts, and Brazil has a comparative disadvantage.

Four tariff lines represent $70 \%$ of Argentina's imports from Egypt. Those are pharmaceutical plants and marble products which are subject to tariff liberalization over four years, and acrylic yarns and parts of water boilers which are subject to tariff liberalization over ten years. As for Uruguay, fertilizers represent more than $61 \%$ of its imports from Egypt. The main type of fertilizers exported to Uruguay is currently subject to a $6 \%$ tariff which will be immediately eliminated upon the agreement's entry into force. 
Table 7. Mercosur Imports from Egypt (Mirror Data for Egypt's Exports to Brazil)- 2014

\begin{tabular}{|c|c|c|c|c|c|c|c|c|c|c|c|}
\hline \multirow[t]{2}{*}{$\begin{array}{l}\text { Product } \\
\text { code }\end{array}$} & \multirow[t]{2}{*}{ Product label } & \multicolumn{3}{|c|}{$\begin{array}{l}\text { Imports from Egypt } \\
\text { (\$ Thousand) }\end{array}$} & \multicolumn{2}{|l|}{ RCA } & \multirow{2}{*}{$\begin{array}{l}\text { Mercosur } \\
\text { Current } \\
\text { Tariff }\end{array}$} & \multicolumn{4}{|c|}{$\begin{array}{l}\text { Categories of Tariff Liberalization under } \\
\text { FTA }\end{array}$} \\
\hline & & Brazil & Argentina & Uruguay & Egypt & Brazil & & Brazil & \begin{tabular}{|l|} 
Argentina \\
\end{tabular} & Paraguay & Uruguay \\
\hline & $\begin{array}{l}\text { Total Imports of each } \\
\text { country from Egypt }\end{array}$ & 146 & 9.6 & 6.7 & - & - & - & - & - & - & - \\
\hline 31031010 & $\begin{array}{l}\text { Superphosphates, less than } \\
22 \% \text { P2O5 content }\end{array}$ & 60.2 & & 1.1 & 33 & 0.6 & 0 & A & B & A & A \\
\hline 31031030 & \begin{tabular}{|ll} 
Superphosphates, more \\
than \\
$45 \% \mathrm{P} 2 \mathrm{O} 2$ content
\end{tabular} & 8.5 & & & 33 & 0.6 & 0 & A & B & A & A \\
\hline 31031020 & $\begin{array}{l}\text { Superphosphates, } \\
22 \%-45 \% \\
\mathrm{P} 2 \mathrm{O} 2 \text { content }\end{array}$ & & & 3.0 & 33 & 0.6 & 6 & A & $\mathrm{D}$ & A & A \\
\hline 90189099 & Medical instruments & 1.4 & & & & & 16 & A & $\mathrm{D}$ & $\mathrm{D}$ & $\mathrm{D}$ \\
\hline 52010020 & $\begin{array}{l}\text { Cotton, neither carded nor } \\
\text { combed }\end{array}$ & 4.5 & & & 4.9 & 7.9 & 6 & B & B & A & B \\
\hline 39012029 & \begin{tabular}{|l|}
$\begin{array}{l}\text { Polyethylene in primary } \\
\text { forms }\end{array}$ \\
\end{tabular} & 2.1 & & & 4.2 & 1.9 & 14 & B & B & B & B \\
\hline 12119090 & \begin{tabular}{|l}
$\begin{array}{l}\text { Pharmaceutical and } \\
\text { perfumery plants }\end{array}$ \\
\end{tabular} & 1.7 & 0.8 & & 31 & 0.4 & 8 & B & B & B & B \\
\hline 20057000 & Prepared/preserved olives & 1.2 & & & 21 & 0.1 & 14 & B & E & $\mathrm{B}$ & $\mathrm{B}$ \\
\hline 82122010 & Safety razor blades & 1.1 & & & 8.1 & 2.8 & 18 & $\mathrm{~B}$ & $\mathrm{D}$ & $\mathrm{D}$ & $\mathrm{B}$ \\
\hline 68029100 & Marble, Alabaster & & & & 1.1 & 0.3 & 6 & $\mathrm{~B}$ & B & B & $\mathrm{B}$ \\
\hline 82121020 & Non-electric razors & 1.0 & & & 1.5 & 2.1 & 18 & B & $\mathrm{D}$ & $\mathrm{C}$ & B \\
\hline 40112090 & New pneumatic tires & 10.6 & & & 2.4 & 1.4 & 16 & $\mathrm{C}$ & $\mathrm{D}$ & $\mathrm{C}$ & $\mathrm{D}$ \\
\hline 31052000 & $\begin{array}{l}\text { Fertilizers of nitrogen, } \\
\text { phosphorus, potassium }\end{array}$ & 3.6 & & & 0.1 & 3.5 & 0 & C & $\mathrm{C}$ & C & $\mathrm{C}$ \\
\hline 76012000 & Aluminum alloys & 1.3 & & & 1.1 & 0.1 & 6 & $\mathrm{C}$ & $\mathrm{C}$ & $\mathrm{C}$ & $\mathrm{C}$ \\
\hline 39206219 & $\begin{array}{l}\text { Non-cellular polyethylene } \\
\text { terephthalate sheets }\end{array}$ & 15.1 & & & 0.01 & 0.1 & 16 & $\mathrm{D}$ & $\mathrm{D}$ & $\mathrm{D}$ & D \\
\hline 55093200 & $\begin{array}{l}\text { Multiple "folded" or } \\
\text { cabled acrylic yarn }\end{array}$ & & 2.6 & & 6.4 & 0.8 & 18 & D & D & D & D \\
\hline 52054300 & $\begin{array}{l}\text { Multiple "folded" or } \\
\text { cabled cotton yarn }\end{array}$ & 2.6 & & & 0.9 & 0.1 & 18 & D & D & D & D \\
\hline 70052100 & $\begin{array}{l}\text { Float glass and surface } \\
\text { ground glass }\end{array}$ & 2.4 & & & 6.2 & 1.5 & 10 & $\mathrm{D}$ & D & $\mathrm{D}$ & D \\
\hline 84029000 & Parts of water boilers & & 2.0 & & & 0.1 & 14 & $\mathrm{D}$ & $\mathrm{D}$ & $\mathrm{D}$ & $\mathrm{D}$ \\
\hline 07122000 & Dried onions & 1.8 & & & 47 & 0.1 & 10 & $\mathrm{D}$ & B & C & $\mathrm{B}$ \\
\hline 61091000 & Cotton T-Shirts & 1.8 & & & 6.5 & 0.1 & 35 & $\mathrm{D}$ & $\mathrm{D}$ & $\mathrm{D}$ & $\mathrm{D}$ \\
\hline 52054200 & $\begin{array}{l}\text { Multiple "folded" or } \\
\text { cabled cotton yarn }\end{array}$ & 1.8 & & & 0.7 & 0.1 & 18 & $\mathrm{D}$ & D & $\mathrm{D}$ & D \\
\hline
\end{tabular}

Category A: Immediate tariff elimination on the date of the agreement's into force; Category B: tariff elimination in four years starting the date of the agreement's entry into force; Category C: Tariff elimination in eight years starting the date of the agreement's entry into force; Category D: Tariff elimination in ten years starting the date of the agreement's entry into force; Category E: Tariff liberalization is to be negotiated.

Source: Trade data are from International Trade Center (2015a); Tariff data are from International Trade Center (2015b) ; Trade Liberalization categories are from Free Trade Agreement between Mercosur and Egypt-Annex II.

\section{Conclusions}

Mercosur countries currently supply 3.6\% of Egypt's imports, and receive $0.4 \%$ of Egypt's exports to the world. Mercosur countries supply 20\% of Egypt's imports of agricultural products. Most of Egypt's current imports from Mercosur are products in which Mercosur has a high revealed comparative advantage, and in which Egypt has a high comparative disadvantage. Therefore, liberalization of tariffs imposed on such products is not expected to 
be associated with negative trade diversion effects which result from diversion of imports towards inefficient producers.

Egypt's exports to Mercosur countries are lower than expected given Mercosur's share in world imports, and Egypt's share in world exports. However, trade complementarity indexes show that there is potential for increased exports from Egypt to Mercosur countries. This is confirmed by the results of revealed comparative advantage analysis which highlight several sectors in which Egypt has comparative advantage and Mercosur countries have comparative disadvantage. Those sectors include fertilizers, carpets, and some types of textiles and apparel. There are also some sectors in which both Egypt and Mercosur countries have comparative advantage. For several of those sectors, there is potential for vertical and horizontal integration between Egypt and Mercosur. Examples include the vegetable oils, sugar, and cotton sectors.

Brazil is Egypt's major export partner among Mercosur countries. Half of Egypt's current exports to Brazil are subject to immediate tariff liberalization when the agreement enters into force. However, the types of superphosphate fertilizers which constitute 47\% of Egypt's exports to Brazil are already subject to zero tariffs. About $10.5 \%$ of Egypt's current exports to Brazil will benefit from tariff liberalization in a period of four years. Those products include ginned cotton, pharmaceutical plants and prepared olives. Also, $15.5 \%$ and $23.4 \%$ of Egypt's exports to Brazil are subject to tariff liberalization over eight and ten years respectively. Those products include dried onions, cotton and acrylic yarn, and cotton T-shirts. Egypt's exports to Argentina mainly comprise pharmaceutical plants and marble products which are subject to tariff liberalization over four years, and acrylic yarns and parts of water boilers which are subject to tariff liberalization over ten years. As for Uruguay, fertilizers represent more than $61 \%$ of its imports from Egypt. The main type of fertilizers exported to Uruguay is currently subject to a $6 \%$ tariff which will be immediately eliminated upon the agreement's entry into force.

The article focused on trade in goods (merchandise trade) between Egypt and Mercosur, and the anticipated tariff liberalization resulting from the agreement. This is because elimination/reduction of tariffs imposed on goods is the main area where the Mercosur-Egypt Free Trade agreement stipulates for a specific plan of action and includes a schedule of commitments. However, tariff liberalization is only one element of economic integration, and is described in the literature as the shallow element of economic integration. Deep integration includes policies and institutions that involve facilitation of trade through simplification of custom procedures, liberalization of trade in services, regulation of investments, and removal of barriers related to product standards and regulations. The Mercosur-Egypt free trade agreement included general text that encourages further negotiation of the above elements of deep economic integration.

Therefore, future research should examine the non-tariff barriers and investment cooperation opportunities in the sectors where the agreement parties have comparative advantage, with a view to providing recommendations for deeper integration between the agreement parties. Given that Egypt is the only African and Arab country to have an agreement ratified with 


\section{Ml Macrothink}

Business and Economic Research ISSN 2162-4860 2017, Vol. 7, No. 2

Mercosur, and Egypt's membership of the pan-European area, Greater Arab Free Trade Area, and Common Market of Southern African Countries (COMESA), there are prospects for Egypt to act as a hub for trade between Mercosur, Middle East, and the European Union. Therefore, comprehensive analysis of the rules of origin of the Egypt-Mercosur Free Trade agreement, and the other agreements, in which the agreement signatories are members of, is paramount. The current free trade negotiations between Mercosur and the European Union should focus on possibilities for enhancing the benefits of the pan-European rules of origin, especially in the sectors which are candidates for vertical integration between Egypt and Mercosur.

\section{References}

Alaraby. (2015). From Rio to Riyadh: Arab and Latin America meet. Retrieved from: http://www.alaraby.co.uk/english/news/2015/11/10/latin-america-states-meet-arab-counterpar ts-in-saudi-arabia.

Balassa, B. (1965). Trade liberalization and Revealed Comparative Advantage. The Manchester School of Economic and Social Studies, 33, 92-123.

https://doi.org/10.1111/j.1467-9957.1965.tb00050.x

Carrieri, M. (2015). Brazil ratifies free trade with Egypt. Arab-Brazilian Chamber of Commerce and Arab-Brazilian News Agency. Retrieved from:

http://www2.anba.com.br/noticia/21869264/diplomacy/brazil-ratifies-free-trade-with-egypt/

COMCEC. (2014). Preferential Trade Agreements and Trade Liberalisation Efforts in the OIC Member States: With Special Emphasis on the TPS-OIC. Standing Committee for Economic and Commercial Cooperation of the Organization of Islamic Cooperation (COMCEC), Ankara, Turkey. Retrieved from:

http://www2.comcec.org/UserFiles/File/WorkingGroups/Trade4/4-Trade-Report.pdf

EkhbaryiaTV, 2015. Arab Latin American Summit- Riyadh Declaration. YouTube Video. Retrieved from: https://www.youtube.com/watch?v=u47M_H4NkPg [Accessed 20 Nov. 2015].

Evans, D., Gasiorek, M., Ghoneim, A., Haynex-Premeph, P., Holmes, P., ... Robinson, S. (2006). Assessing Regional Trade Agreements with Developing Countries: Shallow and Deep Integration, Trade, Productivity, and Economic Performance. University of Sussex: Center for the Analysis of Regional Integration at Sussex, Sussex

Evans, D., Holmes, P., Gasiorek, M., Rollo, J., \& Robinson, S. (2007). Assessing Preferential Trading Agreements. University of Sussex: Center for the Analysis of Regional Integration at Sussex.

International Center for Trade and Sustainable Development (ICTSD). (2010). Mercosur Establishes Customs Code, at Long Last. Bridges Weekly Trade News Digest, 14(29), 3-4.

International Trade Centre. (2015a). Market Access Map. Retrieved from: www.intracen.org/marketanalysis 
International Trade Centre. (2015b). Trade Map. Retrieved from: www.intracen.org/marketanalysis

Menicucci, S., Gonçalves dos Santos, P., \& Paschoal, C. (2014). Brazil as a platform for access to the Southern Common Market. ApexBrasil: Brazilian Trade and Investment

Promotion Agency. Retrieved from: http://arq.apexbrasil.com.br/portal/Anexo5.pdf

Ministério do Desenvolvimento, Indústria e Comércio Exterior (MDIC). (2015). Free Trade Agreement between Mercosur and The Arab Republic of Egypt. Portal de Governo Brasilerio. Retrieved from: http://www.mdic.gov.br/sitio/interna/interna.php?area=5\&menu=2716 4

Pérez, R. (1995). Molasses. In: Tropical Feeds and Feeding Systems, First FAO Electronic Conference. Retrieved from:

http://www.fao.org/livestock/agap/frg/ECONF95/HTML/MOLASSES.HTM

Organization of American STATES.- Foreign Trade Information System (OAS-SICE). (2010). Mercosur and Egypt sign free trade agreement. Retrieved from:

http://www.sice.oas.org/TPD/MER_EGY/MER_EGY_e.asp\#Background

United Nations. (2015). UN comtrade database. Retrieved from: http://comtrade.un.org.

WITS. (2013). Online Trade Outcomes Indicators- User's Manual. Retrieved from: http://wits.worldbank.org/WITS/docs/TradeOutcomes-UserManual.pdf

World Customs Organization. (2012). Correlation Tables 2007-2012. HS 2012 Edition. Retrieved from:

http://www.wcoomd.org/en/topics/nomenclature/instrument-and-tools/hs_nomenclature_2012 1\%20correlations-tables.aspx [Accessed 30 Oct. 2015].

World Trade Organization, (2012). A Practical Guide to Trade Policy Analysis. Retrieved from: https://www.wto.org/english/res_e/publications_e/wto_unctad12_e.pdf

World Trade Organization. (2015). Statistics Database. Retrieved from:

http://stat.wto.org/Home/WSDBHome.aspx?Language=E

\section{Copyright Disclaimer}

Copyright for this article is retained by the author(s), with first publication rights granted to the journal.

This is an open-access article distributed under the terms and conditions of the Creative Commons Attribution license (http://creativecommons.org/licenses/by/3.0/). 